\title{
Otolith strontium traces environmental history of subyearling American shad Alosa sapidissima
}

\author{
Karin E. Limburg \\ Institute of Ecosystem Studies, Box AB, Millbrook, New York 12545, USA
}

\begin{abstract}
A.BSTRACT: Sagittal otoliths of young-of-year American shad Alosa sapidissima from the Hudson River estuary, New York, USA, were transected with an X-ray-dispersive microprobe to examine temporal patterns of strontium, a micro-constituent found in otolith aragonite. Otoliths were assayed from fish reared on known diets (freshwater zooplankton, followed by artificial diet containing marine fishmeal) in fresh water. The switch from freshwater plankton to artificial diet resulted in a significant rise in $\mathrm{Sr}$ : Ca ratio in the otolith (mean increase 3.2 -fold, $\mathrm{p}<0.001$ ) both for fish reared at $12.5^{\circ} \mathrm{C}$ and those reared at $22^{\circ} \mathrm{C}$, although there was no significant difference in $\mathrm{Sr}: \mathrm{Ca}$ increases between the 2 temperature treatments. In a field study, Sr:Ca values of otoliths from wild fish caught in the freshwater reaches of the Hudson were low (mean $0.79 \times 10^{-3} \mathrm{Sr}: \mathrm{Ca} \pm 0.32 \mathrm{SD}$, range 0.00 to $1.46 \times 10^{-3}$ \}. Six fish captured in a single trawl in the lower estuary on 25 September 1990 had low Sr:Ca values on the inner parts of their otoliths (corresponding to younger age: mean $\mathrm{Sr}: \mathrm{Ca}=0.98 \times 10^{-3} \pm 0.38 \mathrm{SD}$ ), but the strontium content increased 3 - to 5 -fold (mean $\mathrm{Sr}: \mathrm{Ca}=3.62 \times 10^{-3} \pm 0.71 \mathrm{SD}$ ) on the outer parts, corresponding to dates when the fish were older. The change in strontium content is consistent with the movement of fish from freshwater to seawater, as seawater has a higher Sr concentration and ratio of $\mathrm{Sr}$ : Ca. The same change was seen in the otolith of a female adult shad and has been documented in other diadromous fishes. Three of these juveniles had such anomalous early growth patterns as to suggest their origin in a natal river other than the Hudson. The estimated seawater entry dates of these fish were as early as late June. This is the first demonstration of such early outmigration, and possibly vagrancy, in young-of-year of this species, and contributes to our understanding of American shad life history.
\end{abstract}

KEY WORDS: American shad - Otolith microchemistry Strontium :calcium ratios $\cdot$ Anadromy $\cdot$ Migration

\section{INTRODUCTION}

Otoliths (earstones) of teleost fishes form a critical part of the acoustico-lateralis system (Moyle \& Cech 1988). In most species, otoliths are composed of aragonite precipitated on a protein matrix (Degens et al. 1969) and appear to accrete new material throughout the life of the fish. Whereas coarse otolith macrostructures (annuli) have long been used to determine the age of fish $\geq 1$ yr (e.g. Reibisch 1900, Dannevig 1933), much work in the past 20 yr has focused on microstructure (e.g. Campana \& Neilson 1985, Brothers 1987). Micro-increments have been shown to accrete daily (Pannella 1971, Brothers et al. 1976), stimulating studies of age estimation in teleosts (Summerfelt \& Hall 1987, Secor et al. 1994).

Chemical composition of otoliths has likewise interested investigators for some time (Dannevig 1956,
Odum 1957b, Degens et al. 1969). Recent advances in $\mathrm{X}$-ray spectroscopy have allowed fine-scale examination of trace inorganic constituents of otoliths (e.g. Radtke 1984, Gauldie et al. 1986, Kalish 1989, Gunn et al. 1992, Secor 1992). Strontium has been of particular interest because of its potential to reveal information about environments in which fish live. Strontium (Sr), like calcium (Ca) an alkaline earth element, has a similar crystal ionic radius $\left(\mathrm{Ca}=0.99 \AA, \mathrm{Sr}=1.13 \AA_{;}\right.$ Atkins 1978), and can substitute into the aragonite crystal lattice as a trace constituent (Degens et al. 1969).

The incorporation of $\mathrm{Sr}$ vs $\mathrm{Ca}$ in inorganic aragonitic precipitations has been found to be inversely correlated with the temperature at which it was deposited (Kinsman \& Holland 1969), and Radtke (1984, 1989) demonstrated a similar relationship in fish otoliths. However, even larger differences in Sr:Ca 
exist when comparing freshwater to marine environments due to the relative scarcity of $\mathrm{Sr}$ in fresh water. Seawater strontium concentration is reported as relatively constant (ca $90 \mu \mathrm{M}$ ) throughout the world's oceans (Table 1). Freshwater strontium can vary considerably due to geology and weathering conditions (Odum 1957b, Durum \& Haffty 1963, Skougstad \& Horr 1963). In the contiguous United States, Sr:Ca levels are generally low in cooler, moister areas and higher in warm, arid ones (Table 1). Distributions of Sr:Ca in U.S. surface waters are typically lognormal: most surface water Sr:Ca ratios are less than $3.5 \times$ $10^{-3}$ (Odum 1957a, Durum \& Haffty 1963, Skougstad \& Horr 1963).

Differences appear in relative $\mathrm{Sr}$ concentrations in otoliths from fish caught in different salinities, as well. For instance, Odum (1957b) noted nearly 5-fold greater $\mathrm{Sr}: \mathrm{Ca}$ in marine (Long Island Sound and the Atlantic Ocean at North Carolina, USA) versus freshwater (Mill Pond, Connecticut) otoliths. More recently, microprobe analysis has shown that otoliths of diadromous fishes exhibit large Sr:Ca fluctuations as the freshwater-marine gradient is traversed (migrating eels in the St. Lawrence: Casselman 1982; Derwent (Tasmania) River anadromous salmonids: Kalish 1990; Chesapeake Bay (USA) striped bass: Secor 1992). Coutant \& Chen (1993), studying strontium levels along transects of striped bass scales from the Roanoke River-Albemarle Sound (North Carolina) system, found patterns consistent with fish being spawned in higher salinity waters and then moving to fresh water.
I report here on 2 applications of the microprobe technique to examine the Sr:Ca ratios measured along transects on otoliths from juvenile American shad Alosa sapidissima, an anadromous herring common along the coastal western Atlantic. In the first application, otoliths were examined from fish that had been part of a growth experiment. These fish were reared entirely in fresh water from a single source, but their diet was switched $42 \mathrm{~d}$ post hatch from naturally occurring zooplankton to an artificial feed containing marine fishmeal, which had elevated strontium relative to the freshwater zooplankton. A set of observations on otoliths from 10 fish from this growth experiment, which lasted $12 \mathrm{wk}$, tests the hypothesis that diet alone can influence the incorporation of $\mathrm{Sr}$ into otoliths.

In a demographic study of the 1990 year-class from the Hudson River, New York, USA (Limburg 1994), several juveniles ( 7 out of 1504 examined) had total lengths $\geq 130 \mathrm{~mm}$ (Fig. 1). In addition, growth rate anomalies were observed in 3 other fish with backcalculated hatch dates in early May. The anomalous fish had otolith growth rate patterns that placed them in the 99 percentile for high growth in May.

Based on length at age or growth rate, these fish, all collected in the lower estuary between river kilometers (Km) 39 and 69, represented outliers in the population. In the second application, microprobe analysis was used to test the hypothesis that these individuals were not from the Hudson-spawned population, but rather were vagrants (sensu Sinclair 1988) from a different river system.

Table 1. Reported concentrations of strontium and calcium in marine and fresh water. Errors are standard deviations unless stated otherwise

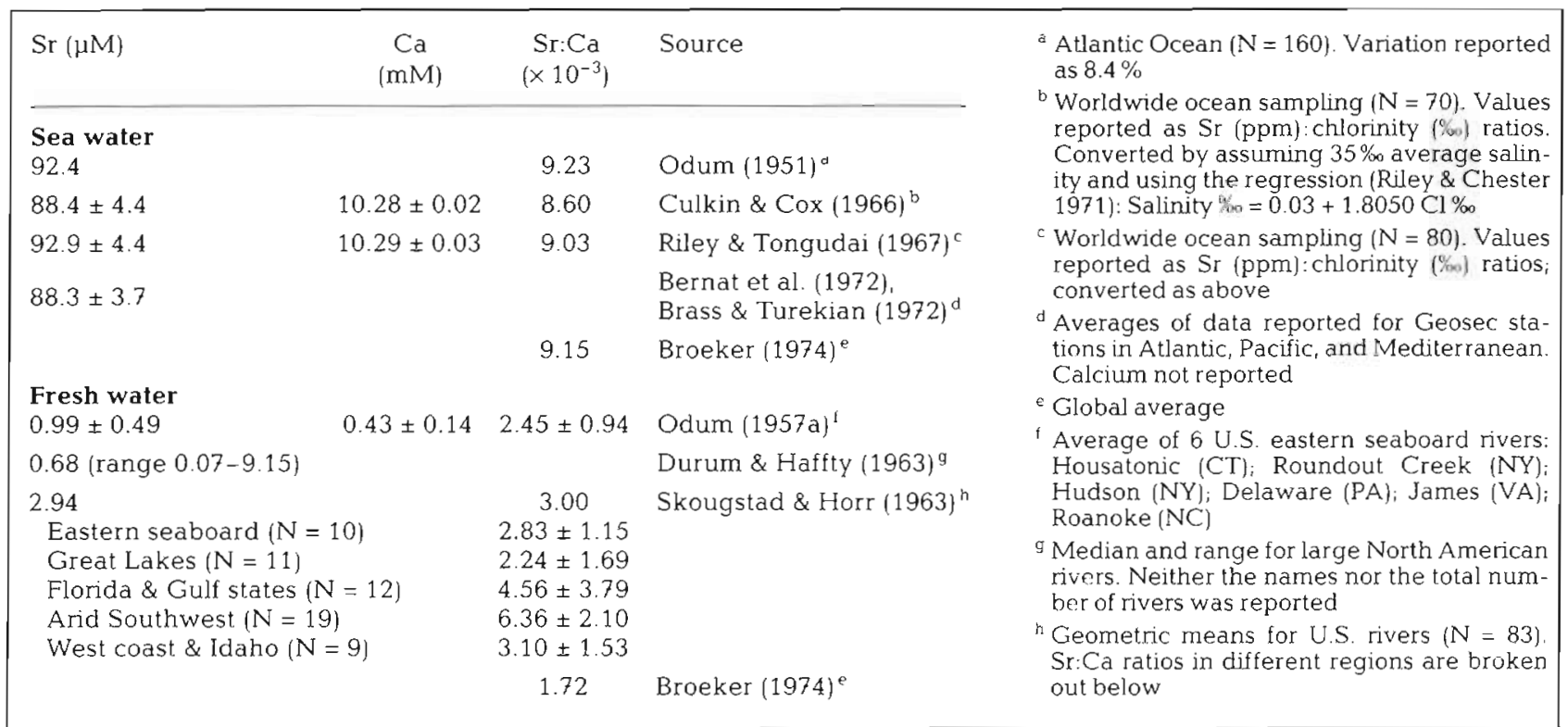




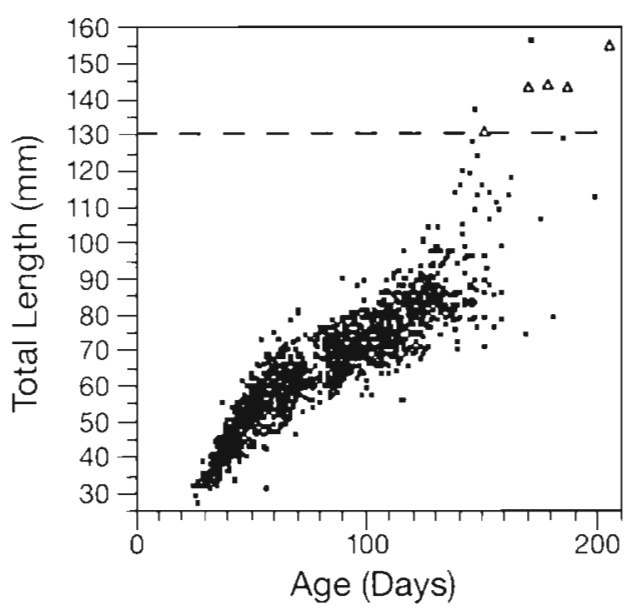

Fig. 1. Alosa sapidissima. Plot of total length at age of 1504 juvenile American shad collected in 1990. Dashed line indicates anomalously large fish (99.5 percentile); triangles mark fish analyzed in this study

\section{MATERIALS AND METHODS}

Study sites. The Hudson River is located in eastern New York State and drains some $34680 \mathrm{~km}^{2}$. It flows in a southerly direction for $507 \mathrm{~km}$, draining into the New York Bight at New York Bay (Limburg et al. 1986). A dam located at Km 245 (Green Island) separates the upper, nontidal river from the lower, tidal portion. The lower Hudson, a partially stratified estuary (Abood 1974), receives salt water through the Verrazano Narrows in New York Bay. The extent of seawater intrusion varies with seasonal freshwater river flows (Abood 1974, Simpson et al. 1974). During summertime low freshwater flows, the salt front $(0.5 \%)$ is usually located ca 80 to $100 \mathrm{~km}$ up the estuary (Abood 1974). Vertical salinity stratification is usually weak at this time due to mixing (McCrone 1966, Busby \& Darmer 1970, Abood 1974, Simpson et al. 1974) but surface-to-bottom gradients of $10 \%$ at Piermont (river Km 40) can occur (Simpson et al. 1974).

American shad use the tidal part of the river exclusively. Adult shad enter the Hudson in late March or early April, and spawn in fresh water from Km 145 to 245 (peak Km 182) for a prolonged period when temperatures occur between 14 and $20^{\circ} \mathrm{C}$ (Talbot 1954 , Schmidt et al. 1988). Juveniles are found throughout the tidal riverine-estuarine system from July through November, but exit before the onset of winter.

Laboratory study. Laboratory studies were conducted at the National Fishery Research and Development Laboratory (NFRDL), United States Fish and Wildlife Service, located in Wellsboro, Pennsylvania. Experimental fish, of Hudson River origin, were reared from fertilized eggs ( 8 male and 15 female parents).
18 d old larvae were obtained from the Van Dyke Hatchery, Thompsontown, Pennsylvania, in June 1989 and transferred into an artificial rearing pond at NFRDL, and reared to approximately $50 \mathrm{~mm}$ total length (TL). After $24 \mathrm{~d}$ in the pond, the fish were given an open-formula feed, A.SD-20 (Lemm et al. 1988). Two days later, approximately 1200 fish were collected from the pond and transported to the laboratory, using modifications of techniques described in Backman \& Ross (1991). In the laboratory, fish were held in 5001 tanks for a 12 wk growth experiment. The water source for the pond and the lab were identical; both pond and tanks were fed continuously by fresh inflow. Fish were fed at 3 different ration levels on ASD-20 and held at 3 different temperatures. Full details of the growth experiment are described in Limburg (1994). For the present study, otoliths were selected from 5 fish reared in a $22^{\circ} \mathrm{C}$, satiation ration treatment, and from 5 fish from a $12.5^{\circ} \mathrm{C}$, satiation ration treatment, in order to test for temperature-mediated differences in Sr uptake.

Wild fish collections. Wild fish were collected during the summer and fall of 1990 at 1 upriver, 1 mid-river, and 2 downriver sites (Fig. 2, Table 2). Collections were made either with a $30.5 \mathrm{~m}$ bag seine $(0.64 \mathrm{~cm}$ bar mesh), or with a $7.9 \mathrm{~m}$ headrope Carolina wing bottom trawl $(3.8,3.2$, and $1.3 \mathrm{~cm}$ in the trawl body, cod end, and cod liner, respectively).

Fish for microchemical otolith analysis were selected at random from 4 upriver (Albany: Km 240) and 4 midriver (Poughkeepsie: $\mathrm{Km} \mathrm{120)}$ individuals to provide data on the freshwater $\mathrm{Sr}$ : Ca baseline. Seven randomly selected fish were examined from the downriver beach seine site (Tappan Zee: Km 39 to 50). These fish had otolith microstructures which were typical for most juveniles collected throughout the Hudson River in 1990. Three fish with otolith microstructures that showed atypically high growth rates in May and 3 other fish (all 6 collected by bottom trawl in Haver-

Table 2. Description of sampling sites and gear used in 1990 Hudson River collections. Salinity regimes are as defined in Limburg et al. (1986)

\begin{tabular}{|lccc|}
\hline Site name & $\begin{array}{c}\text { Distance from } \\
\text { mouth }(\mathrm{Km})\end{array}$ & $\begin{array}{c}\text { Salinity } \\
\text { regime }\end{array}$ & $\begin{array}{c}\text { Gear } \\
\text { type }\end{array}$ \\
\hline Albany & 240 & $\begin{array}{c}\text { Freshwater } \\
(\leq 0.5 \%)\end{array}$ & Seine \\
Poughkeepsie & 120 & $\begin{array}{c}\text { Freshwater } \\
(\leq 0.5 \%)\end{array}$ & Seine \\
Haverstraw Bay & 39 to 69 & $\begin{array}{c}\text { Mesohaline } \\
(5 \text { to } 18 \%) \\
\text { Mesohaline } \\
(5 \text { to } 18 \%)\end{array}$ & Trawl \\
Tappan Zee & 39 to 50 & Seine \\
\hline
\end{tabular}




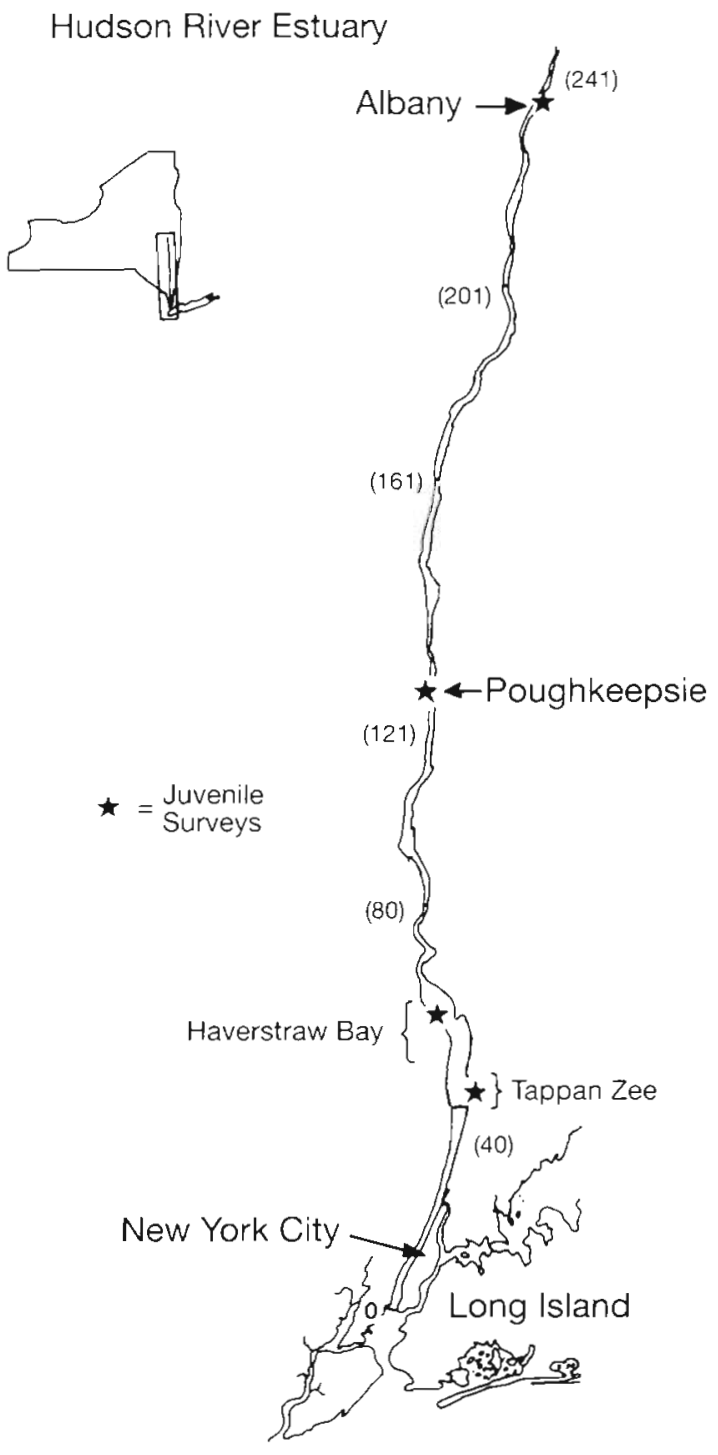

Fig. 2. Map of the tidal Hudson River showing sampling stations. Numbers in parentheses are river kilometers from the mouth

straw Bay on 25 September 1990) were also examined. Otoliths were also assayed from 5 young-of-year shad of unusually large size (>130 mm TL), collected in the lower estuary in early November Finally, the sagittal otolith from a single adult female, caught at Kingston, New York (Km 145) during the 1991 spawning run, was probed.

Otolith preparation. Sagittal otoliths were extracted, cleaned with $10 \%$ sodium hypochlorite (bleach), airdried, and subsequently embedded in Spurr epoxy. The cured plastic stubs containing the otoliths were ground to roughly $0.5 \mathrm{~mm}$ thickness. Otoliths were then ground to approximately the mid-sagittal plane to expose the core, and polished with the following series of $3 \mathrm{M}$ lapping papers: $30,15,9,5$, and $3 \mu \mathrm{m}$. American shad otoliths are relatively flat, so grinding to expose the core did not result in loss of outer-most increments. After examination of microstructures, the otoliths were re-polished, this time down to $0.5 \mathrm{~mm}$. The otolith surface was cleaned with $95 \%$ ethanol between polishings. Final cleaning was with ultrasonication, using isopropanol as the cleaning agent. Otolith stubs were then mounted on slides and coated with carbon ( $\sim 250 \AA$ thickness) by high-vacuum evaporation.

Otolith microstructure. Otoliths were examined with a Leitz Orthoplan compound microscope with video attachment. Daily increments have been validated for larval and juvenile American shad (Savoy \& Crecco 1987, Limburg 1994). Increments were counted ( 2 to $3 \times$ ) on the major posterior axis. Increment widths were measured by placing cash register tape on the video screen and marking increments on the tape. Distortion due to curvature of the screen was slight $(<5 \%)$. Increment marks were then digitized with a Graf/Bar GP-7 sonic digitizer (Science Accessories Corporation) and normalized to the length of the major posterior axis. Precision on counts was $\pm 3 \mathrm{~d}$ and accuracy on known-age juveniles was within $5 \%$ (Limburg 1994)

Microprobe analysis. Sr and Ca concentrations were quantified with a JEOL 733 wavelength dispersive electron microprobe at the Materials Science Center EM Facility, Cornell University, New York. Following recommendations by Gunn et al. (1992), long counting times along with a wide beam diameter of $20 \mu \mathrm{m}$ were used to collect Sr counts; this reduces specimen damage and improves the quality of the data. Accelerating voltage was set at $20 \mathrm{kV}$ and probe current at $20 \mathrm{nA}$. Sr was counted for $60 \mathrm{~s}$ and Ca for $20 \mathrm{~s}$. Background was measured for $30 \mathrm{~s}$ on each side of the $\mathrm{Sr}$ peak and subtracted. Calcite was used for the calcium standard. The Sr standard was Corning Glass ' $\mathrm{X}$ ' (distributed by the Microbeam Analysis Society), which has a low concentration of $\mathrm{SrO}(0.79 \%$ by weight $)$ and is thus suitable for trace element analysis. Weight percents of $\mathrm{SrO}$ and $\mathrm{CaO}$ were computed from X-ray counts with the Bence-Albee correction factors (Albee \& Ray 1970), and converted to atom percents of Sr and $\mathrm{Ca}$, respectively. Precision of $\mathrm{Ca}$ and $\mathrm{Sr}$ (as measured on the standards) was 0.2 and $1.4 \%$, respectively (Goldstein et al. 1981). The minimum detectable level of Sr was 290 ppm. Results are given as atoms Sr per 1000 atoms Ca.

Transects were made along the longest posterior axis of the otolith, as had been done for measuring growth. Between 9 and 20 equally spaced points were assayed, with interpoint distances ranging from 25 to $99 \mu \mathrm{m}$ apart, depending on the size of the otolith and the number of data points read. After microprobe measurements, the distance of the first point (visible as a 
faint mark on the carbon coating) to the otolith primordium was measured with an ocular micrometer.

Analysis of artificial diet. A sample of the diet fed to fish at NFRDL was archived and analyzed for $\mathrm{Sr}$ and $\mathrm{Ca}$ with inductively coupled argon plasma atomic emission spectrometry (ICP) at the Nutrient Analytical Laboratory, Food and Vegetable Science Department, Cornell University. $300 \mathrm{mg}$ of sample was digested in $2.0 \mathrm{ml}$ redistilled $\mathrm{HNO}_{3}$ and $0.250 \mathrm{ml}$ ultrapure $\mathrm{HClO}_{4}$ at 180 to $200^{\circ} \mathrm{C}$ for several hours until near dryness, redissolved in $0.5 \mathrm{ml} \mathrm{HCl}$ and brought to $10.0 \mathrm{ml}$ with distilled $\mathrm{H}_{2} \mathrm{O}$, and read on the ICP. Sample error was within $1 \%$. Blanks $(5 \% \mathrm{HCl})$ did not contain measureable amounts of either element.

\section{RESULTS}

\section{Laboratory fish}

Fish reared for laboratory experiments showed marked changes in $\mathrm{Sr}: \mathrm{Ca}$ that corresponded to changes in diet, as seen in 2 typical Sr:Ca transects (Fig. 3). For all but 3 of the fish, initial values were very low (Table 3). Otoliths that were sampled directly on the primordium had low values, in contrast with anadromous salmonids (Kalish 1990). Otoliths of the remaining 3 fish had moderately high initial Sr:Ca values, followed by low values, then followed by high values again as the fish were brought into the laboratory, In many cases, the otolith was sampled during the pond period just when fish had been introduced to the artificial diet; this was reflected as an increase in $\mathrm{Sr}$ :Ca. Once in the laboratory, fed entirely on artificial diet, Sr:Ca values quickly reached a maximum value and then declined somewhat (Fig. 3). This may have been due to a slow-down in growth rate over time.

Table 3. Sr:Ca ratios $\left(\times 10^{-3}\right)$ for 10 fish reared $18 \mathrm{~d}$ in a hatchery, $26 \mathrm{~d}$ in an artificial pond, and $144 \mathrm{~d}$ in the laboratory. Means for the hatchery/pond do not include data reflecting the introduction of artificial diet (ASD-20) into the pond

\begin{tabular}{|ccccc|}
\hline Fish ID & $\begin{array}{c}\text { Lab. rearing } \\
\text { temp. }\left({ }^{\circ} \mathrm{C}\right)\end{array}$ & \multicolumn{2}{c}{ Average Sr:Ca $( \pm \mathrm{SE})$} & Max. Sr:Ca \\
& Hatchery/pond & Lab & in the lab \\
\hline $\mathrm{C} 1-\mathrm{X} 7$ & 22 & $0.20(0.10)$ & $1.59(0.13)$ & 2.14 \\
$\mathrm{C} 1-\mathrm{X} 2$ & 22 & $0.21(0.08)$ & $1.46(0.13)$ & 2.17 \\
$\mathrm{C} 1-\mathrm{X} 11$ & 22 & $1.23(0.30)$ & $1.46(0.11)$ & 2.17 \\
$\mathrm{C} 1-\mathrm{X} 8$ & 22 & $0.99(0.18)$ & $1.32(0.10)$ & 2.01 \\
$\mathrm{C} 1-\mathrm{X} 4$ & 22 & $0.31(0.08)$ & $1.15(0.15)$ & 2.02 \\
$\mathrm{~A} 3-08$ & 12.5 & $1.01(0.31)$ & $1.09(0.16)$ & 1.57 \\
$\mathrm{~A} 3-07$ & 12.5 & $0.31(0.07)$ & $0.99(0.22)$ & 1.82 \\
$\mathrm{~A} 3-11$ & 12.5 & $0.43(0.09)$ & $1.00(0.15)$ & 1.59 \\
$\mathrm{~A} 3-20$ & 12.5 & $0.43(0.13)$ & $0.98(0.13)$ & 1.45 \\
$\mathrm{~A} 3-22$ & 12.5 & $0.29(0.08)$ & $0.70(0.13)$ & 1.19 \\
& & & & \\
\hline
\end{tabular}

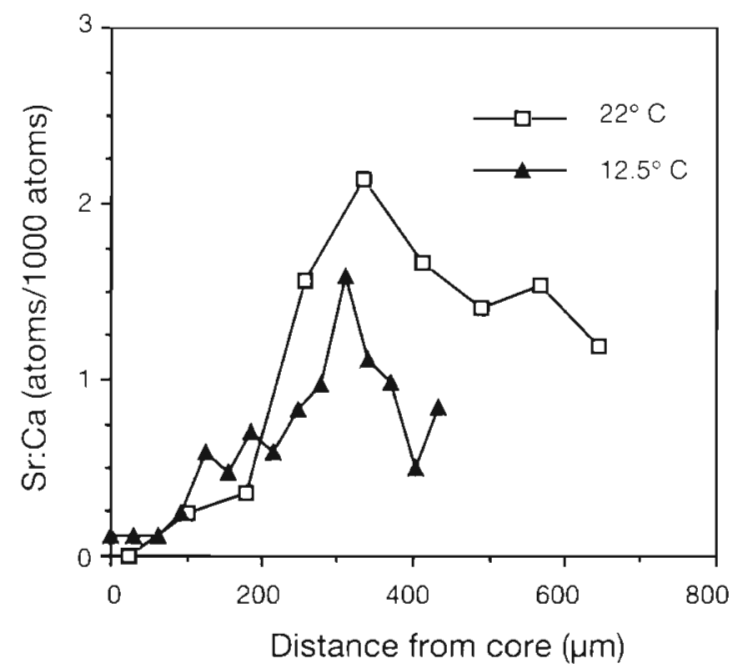

Fig. 3. Alosa sapidissima. Comparison of Sr:Ca transects from fish reared in the laboratory at 2 different temperatures. The peak Sr:Ca values occur just after the fish were moved into the laboratory. The data point just prior to the peak is from the rearing pond and reflects the introduction of ASD-20 diet into the pond

Repeated measures analyses of variance (ANOVA) revealed that diet was the main source of variation $(p<0.0001)$. Neither laboratory temperature treatment nor diet by temperature treatment had significant effects on otolith $\mathrm{Sr}: \mathrm{Ca}$, due to within-subject variability and small sample size (necessitated by cost constraints).

Sr in the artificial diet, determined by ICP analysis, was 158 ppm and Ca was 19180 ppm, giving a Sr:Ca ratio of $3.77 \times 10^{-3}$ (atom basis). The averaged peak value (reflecting maximum incorporation of $\mathrm{Sr}$ ) of the pooled 22 and $12.5^{\circ} \mathrm{C}$ treatments is $1.77 \times 10^{-3} \pm$ $0.39 \times 10^{-3}$ (mean $2.10 \times 10^{-3}$ at $22^{\circ} \mathrm{C}$ and $1.52 \times 10^{-3}$ at $12.5^{\circ} \mathrm{C}$ ). The average $\mathrm{Sr}: \mathrm{Ca}$ for the hatchery/pond phase is $0.31 \times 10^{-3}$ without the 3 fish with high initial values, and $0.54 \times 10^{-3}$ with all fish. Using the latter number as the freshwater baseline, the artificial diet caused an increase in Sr:Ca of up to 3.3 times, averaged across all 10 fish. During uptake from the artificial diet, Sr was discriminated against by a factor of 3.06 $\left[=\mathrm{Sr}: \mathrm{Ca}_{\mathrm{ASD}-20} \div\left(\mathrm{Sr}: \mathrm{Ca}_{\mathrm{Lab} \text { max }}-\mathrm{Sr}: \mathrm{Ca}_{\text {pond avg }}\right)\right]$.

\section{Wild fish observations}

Typical transects of individual fish assayed from each river region are shown in Fig. 4 and mean regional values from all fish in Fig. 5. Fish from freshwater reaches of the Hudson River had low Sr:Ca ratios (Fig. 4a, b). Values ranged 
Table 4. Sr:Ca levels (atoms $\mathrm{Sr} / 1000$ atoms $\mathrm{Ca}$ ) reported in freshwater fish otoliths

\begin{tabular}{|llccl|}
\hline Species & Location & Mean & Range & Source \\
\hline Lepomis gibbosus & Connecticut, USA & 0.92 & $0.8-1.36$ & Odum (1957b) \\
Oncorhynchus mykiss & Tasmania & 0.95 & $0.83-1.07$ & Kalish (1990) \\
Salmo trutta & Tasmania & 0.8 & $0.4-1.1$ & Kalish (1990) \\
Carassius aurata & Japan & 0.4 & $0.2-0.6$ & Mugiya et al. (1991) \\
Morone saxatilis & S. Carolina, USA & 0.59 & $0.19-1.00$ & Secor (1992) \\
Anguilla spp. & Canada and Ireland & 1.4 & $1.0-1.9$ & Casselman (1982) $^{\text {a }}$ \\
Alosa sapidissima & Hudson River (Km 120 to 240) & 0.79 & $0.57-1.13$ & This study \\
a Values reported from those parts of otoliths of anadromous fish that the authors state represent deposition in fresh water & \\
\hline
\end{tabular}

from 0 (below Sr detection limit) to $1.46 \times 10^{-3}$. Mean values of transects from fish collected in Albany (upriver) were slightly higher than those collected in Poughkeepsie (Fig. 5), but not significantly so $\left(F_{1,6}=\right.$

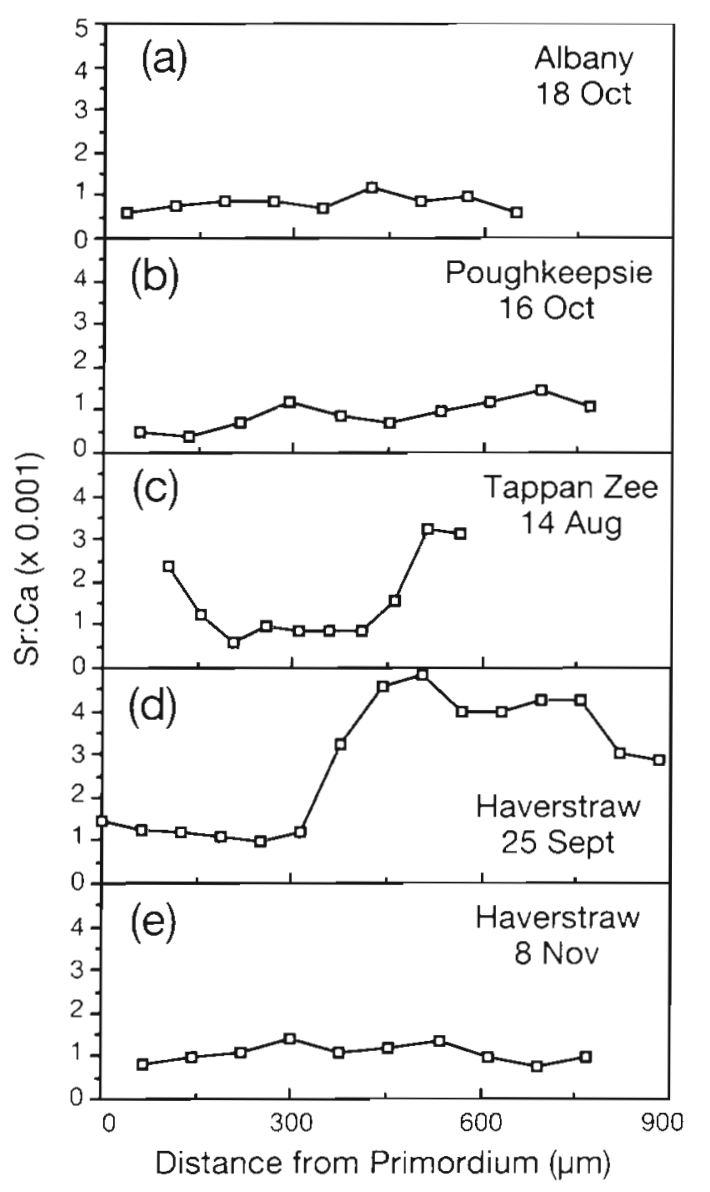

Fig. 4. Alosa sapidissima. Representative otolith Sr:Ca transects from individual fish collected in different regions of the estuary. (a) Upper estuary near Albany, New York ( $\mathrm{Km} 240$ ). (b) Mid-estuary near Poughkeepsie (Km 120). (c) Nearshore habitats in the lower Hudson River estuary, Tappan Zee area ( $\mathrm{Km} 39$ to 50). (d) Offshore habitats in the lower Hudson River estuary, Haverstraw Bay and Tappan Zee ( $\mathrm{Km} 39$ to 69). (e) Offshore in Iower estuary
$2.757, p=0.148$ ). These results are consistent with data reported for fish from other freshwater environments (Table 4).

Otoliths from fish collected in near-shore habitats in the oligo-to mesohaline stretch of the estuary (Tappan Zee) showed more variability. One fish in particular, caught 14 August (Fig. 4c), had 3-fold variation in $\mathrm{Sr}: \mathrm{Ca}$. The pattern of $\mathrm{Sr}: \mathrm{Ca}$ along that transect suggests an early experience with elevated $\mathrm{Sr}$, then a decline, and finally a marked increase. Another fish, caught 18 October, had elevated Sr: $\mathrm{Ca}$ in the middle and the end of the transect. These excursions were higher than any values recorded in the freshwater reaches, and when the otoliths were re-assayed in the same regions, were repeatable.

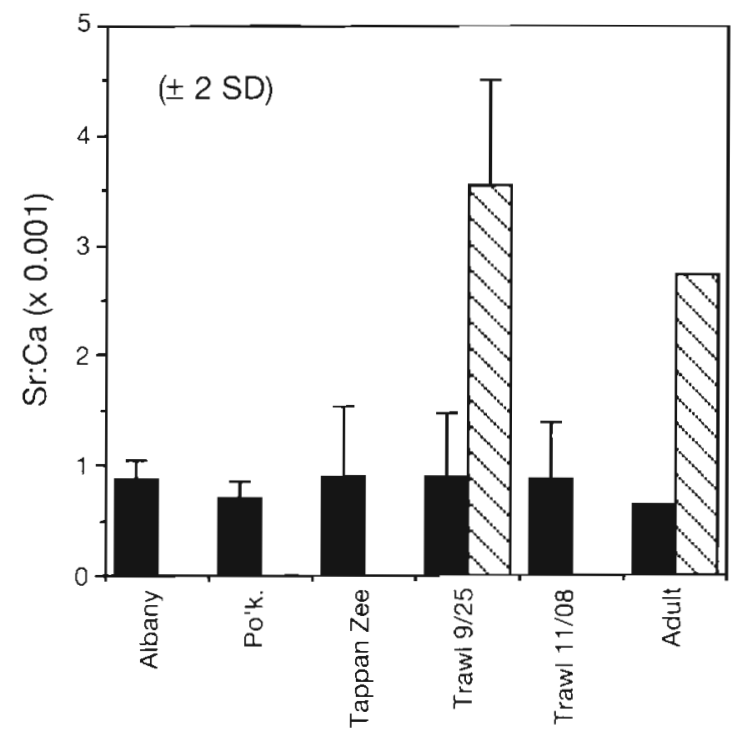

Fig. 5. Alosa sapidissima. Mean otolith Sr:Ca ratios from wild American shad collected in the Hudson River. Black bars indicate average whole-transect values for fish in Albany, Poughkeepsie, Tappan Zee, and the 8 November lower estuarine trawl, and only the presumed freshwater phase of 25 September lower estuarine trawl-collected and adult shad. Striped bars show mean transect values for the presumed seawater phase of the adult and the fish collected on 25 September 


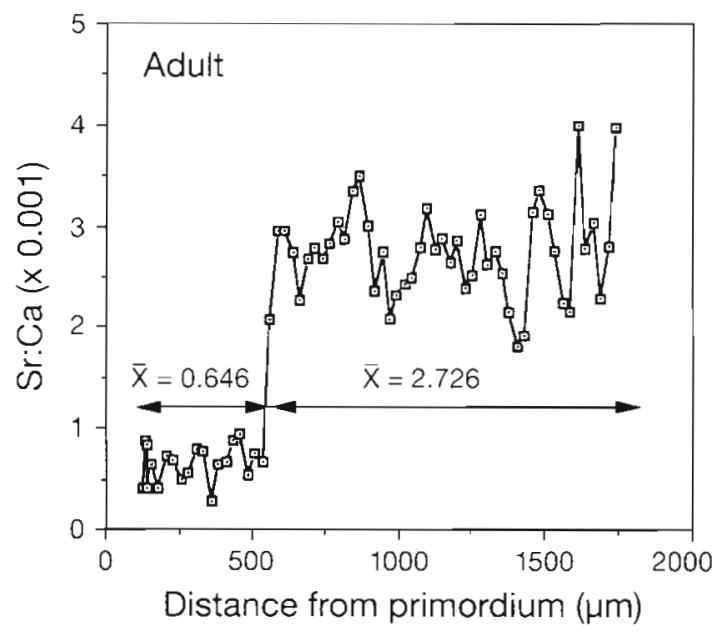

Fig. 6. Alosa sapidissima. Otolith Sr:Ca transect of female adult shad (age 4) caught near Km 145, May 1991

Sr:Ca transects of otoliths from young-of-year fishes that were suspected 'vagrants' (meaning they originated in a non-Hudson River population but entered the Hudson), collected by bottom trawl in the lower estuary (Haverstraw Bay), show different patterns (Fig. 4d). All 6 specimens examined from 25 Sep-

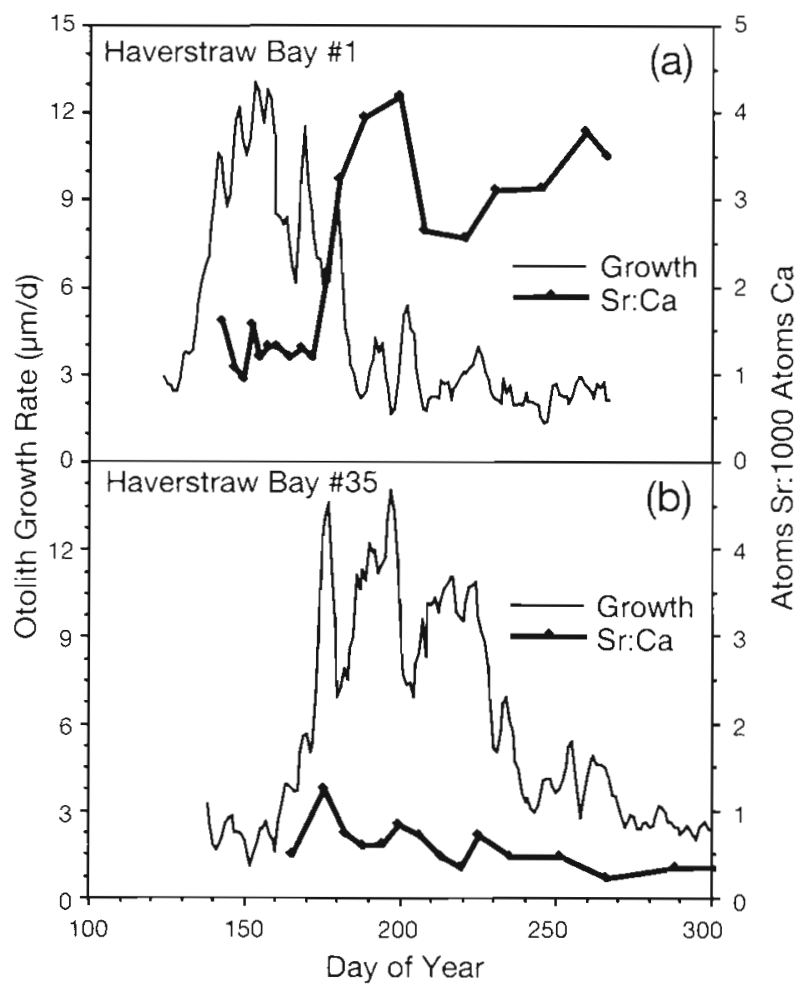

Fig. 7. Alosa sapidissima. Time-series plots of daily otolith growth rate and $\mathrm{Sr}$ :Ca for a migrant and a resident fish. (a) Fish caught in Haverstraw Bay trawl, 25 September 1990. (b) Fish caught in Haverstraw Bay trawl 8 November 1990 tember show a pattern of initially low Sr:Ca, followed by rapid increases, indicative of movement into a marine environment (Radtke et al. 1988). Mean increases (averaging the presumed 'freshwater' and 'marine' data) ranged from 250 to $620 \%$ in the 6 fish, and are in good agreement with the Sr:Ca record from the otolith of an adult shad (Fig. 6) and with adult anadromous striped bass (Secor 1992). In contrast, anomalously large specimens collected on 8 November (Figs. 4e \& Fig. 5) show low Sr:Ca values consistent with data presented for freshwater resident fish.

Daily otolith increment widths and superimposed Sr:Ca transects for 1 of the Haverstraw Bay fish collected on 25 September (Fig. 7a), and for a fish collected in the same region in early November (Fig. 7 b) show different patterns. The otolith growth tracks differ markedly in the timing of peak growth: the September-caught fish shows a peak in early June (Days 150 to 160 ), whereas the maxima in the November-caught fish center on Days 190 to 200 (mid-July). Growth rates in the first $30 \mathrm{~d}$ differ dramatically, despite proximity in back-calculated hatch dates: the November fish shows growth that agrees with the growth of larvae collected in late May and June 1990 (LMS 1992, Limburg 1994), and with water temperature data (LMS 1992). When compared statistically with the distribution of average May growth rates of fish hatched before 16 May, the probability that the fish shown in Fig. 7a belonged to the Hudson population is very low $(z=4.280$; $p<$ $\left.10^{-4}\right)$

The increase in Sr:Ca (Fig. 7a) appears to coincide with a decline in otolith growth rate. This may be fortuitous, as growth rate increases and declines are typical also of fish in freshwater habitats (Fig. 7b), without corresponding changes in Sr:Ca. Estimated 'sea entry dates' (dates when Sr:Ca rises on the otolith transect) for all fishes collected 25 September occur in June through mid August (Table 5).

Table 5. Total lengths (TL) at capture, estimated dates of entering seawater (defined as when $\mathrm{Sr}: \mathrm{Ca}$ values increase above $2.5 \times 10^{-3}$ ), and estimated age of fishes when entering seawater for shad collected in the Hudson River, Km 39 to 69. 25 September 1990

\begin{tabular}{|rccc|}
\hline ID & TL $(\mathrm{mm})$ & \multicolumn{2}{c|}{ Seawater entry } \\
& & Date & Age (d) \\
\hline 1 & 80 & 25 June & 52 \\
11 & 79 & 28 June & 51 \\
13 & 75 & 13 July & 41 \\
16 & 85 & 27 June & 48 \\
20 & 72 & 5 July & 65 \\
21 & 75 & 14 August & 65 \\
\hline
\end{tabular}




\section{DISCUSSION}

\section{Sr uptake from food}

Fish reared in fresh water had significantly higher otolith Sr:Ca ratios when switched from a diet of freshwater zooplankton to artificial food containing at least $50 \%$ marine herring and shrimp. The magnitude of Sr:Ca increase (average 3.3 times) was not quite as large as that reported by Mugiya et al. (1991). In that study, goldfish were exposed to $10 \mathrm{mg} \mathrm{l}^{-1} \mathrm{Sr}$ in solution, and showed a $>5$-fold increase in otolith $\mathrm{Sr}: \mathrm{Ca}$ over controls.

In the present study, within-subject variability was great enough to swamp the possible effects of temperature on Sr uptake by fish in the lab. However, fish reared at $22^{\circ} \mathrm{C}$ consistently had higher $\mathrm{Sr}$ : Ca values than fish reared at $12.5^{\circ} \mathrm{C}$ (Table 3 ), and a temperature effect might have been detectable with a larger sample size. Hoff \& Fuiman (1993) found an increase in both $\mathrm{Sr}$ and $\mathrm{Ca}$ in red drum Sciaenops ocellatus otoliths with increasing temperature and age. In the fish I examined, the relationship appears more closely coupled with growth rate, since highest rates of Sr incorporation occurred shortly after the fish were moved into the laboratory when the otoliths were still growing rapidly, and declined as otolith growth rates decelerated, even as the temperature remained constant. On the other hand, the observed peaks in otolith $\mathrm{Sr}$ :Ca may also be associated with the stress of being moved from the pond into the laboratory; further work would be required to separate the effects of diet and stress.

\section{Sr:Ca in wild fish otoliths}

Otolith strontium concentration is affected by salinity more than it is affected by temperature (Secor et al. 1995). Although the degree to which otolith $\mathrm{Sr}$ varies along a seawater gradient has not been verified for American shad, the results in this study are consistent with previous findings (Casselman 1982, Radtke et al. 1988, Kalish 1989, 1990, Secor 1992).

Because a large part of the Hudson valley is composed of marine carbonates, it is of interest to know the Sr:Ca ratios of Hudson valley bedrock, and how bedrock influences strontium and calcium in river water. The lower Hudson drainage runs through limestone (Km 160 to 250), shales and slates ( $\mathrm{Km} 100$ to 160), and further south a mix of igneous, metamorphic, and sandstone rock (Johnsen 1966). Limestones have relatively low $\mathrm{Sr}$ : Ca ratios (average $0.81 \pm 0.83 \mathrm{SD} \times$ $10^{-3}$; Kulp et al. 1952). Odum (1957b) suggested that these low ratios were due not only to the predominance of calcite, the crystal lattice of which does not incorporate $\mathrm{Sr}$ as readily as aragonite, but also because processes that cause calcite deposition may in turn release strontium into solution. Shales collected in the Hudson valley and adjoining Catskills were enriched in $\mathrm{Sr}$ compared to carbonates (range 1.55 to $12.62 \times$ $10^{-3} \mathrm{Sr}: \mathrm{Ca}$; Turekian \& Kulp 1956). Adirondack rock (mainly Canadian Shield anorthosite), which underlies the uppermost Hudson drainage, is strontium enriched (average of 4 samples, $49.98 \times 10^{-3} \mathrm{Sr}: \mathrm{Ca}, 10.09 \times 10^{-3}$ SD; Turekian \& Kulp 1956).

Relatively few data exist on $\mathrm{Sr}$ :Ca ratios in Hudson River waters. Fabricand et al. (1968) measured strontium, calcium, and salinity Iongitudinally on the Hudson from Km 56 to 240 in July 1965. A minimum of $1.62 \times 10^{-3} \mathrm{Sr}: \mathrm{Ca}$ was found at $\mathrm{Km} 180$ (North Germantown) and increased to $3.08 \times 10^{-3}$ at $\mathrm{Km} \mathrm{240.} \mathrm{The}$ highest ratio $\left(7.32 \times 10^{-3}\right)$ was found in bottom waters at $\mathrm{Km} 56$ (Tappan Zee). In 1990, Sr:Ca values in the Hudson River measured at Green Island ( $\mathrm{Km}$ 245) averaged $2.45 \pm 0.14 \times 10^{-3}(\mathrm{~N}=4 i$ Firda et al. 1991) in good agreement with Mohawk River data $\left(2.66 \times 10^{-3}\right)$ presented by Skougstad \& Horr (1963). The Sr:Ca minimum in Hudson River water between Poughkeepsie and Germantown ( $\mathrm{Km} 120$ to 180$)$ may reflect passage through low Sr:Ca drainages. Otoliths of shad collected in Poughkeepsie had slightly lower Sr:Ca ratios compared to Albany shad (Fig. 5).

Otolith Sr:Ca was generally low $\left(<2 \times 10^{-3)}\right.$ in wild Hudson River fish, with the notable exception of 6 fish collected by bottom trawl in the lower estuary. Since these fish all came from the same net haul, it is possible they were part of a school that had wandered in to the Hudson from saline waters surrounding New York Bay, i.e. the New York Bight or Long Island Sound. Odum (1957a) reported Sr:Ca values for Long Island Sound averaging $9.39 \times 10^{-3}\left( \pm 1.10 \times 10^{-3} \mathrm{SD}\right)$ and 1 datum from the Hudson River at Poughkeepsie, New York of $2.65 \times 10^{-3}$. The 3.5 -fold difference in seawater versus freshwater Hudson $\mathrm{Sr}$ : Ca is consistent with differences observed in the migrating fish.

Alternatively, these fish may have moved into higher salinity bottom waters near the estuary mouth. Mean bottom salinities in the lower estuary (Yonkers vicinity, $\mathrm{Km} 19$ to 32 ) ranged from 3.3 to $11.4 \%$ during JuneOctober (LMS 1992). A single datum exists from Fabricand et al. (1968) of $7.32 \times 10^{-3} \mathrm{Sr}: \mathrm{Ca}$ at $10.2 \%$ salinity. This value is 4.5 times higher than the minimum reported in the same study. Such a difference is also consistent with differences seen in the shad otoliths, albeit from a single data point. Further collection of strontium data in the lower Hudson, in combination with controlled rearing of shad in different salinities, would help to clarify whether shad could pick up sufficient strontium in the lower estuary to show patterns as in Fig. 4d. 
When the Sr:Ca data are aligned with otolith growth data to obtain estimates of calendar dates corresponding to the Sr:Ca samples, $\mathrm{Sr}$ :Ca levels rise in late June through mid August (Table 5), indicating early experience with elevated salinity. It is likely that at least 3 of the fish were of Hudson River origin, based upon otolith microstructure. The 3 remaining fish showed 4 - to 5-fold higher growth rates in late May and early June than would be expected from otoliths of larvae collected during that period (Limburg 1994). Growth rates of larvae, which were collected throughout the tidal Hudson River, corresponded well with temperature records in May and June (LMS 1992). The entire Hudson was cool during May $\left(14.3^{\circ} \mathrm{C}, \mathrm{Km} 0\right.$ and 120), due in part to heavy rainfalls (Limburg 1994) and larval lengths remained around 10 to $12 \mathrm{~mm}$ (LMS 1992) with correspondingly low otolith increment widths (Limburg 1994). The larval and thermal data are at odds with the otolith growth tracks of the remaining 3 fish collected on 25 September. While it is possible these fish had discovered a completely different (most likely warmer) environment within the Hudson, it is also possible that they were hatched in another river system with a different thermal regime during May. The evidence from fish size distributions, otolith growth rates, and hydrographic data (Limburg 1994) points to the second possibility.

None of the other trawl-collected fish (8 November) showed elevated Sr:Ca ratios, nor were their otolith growth patterns atypical when compared to other fishes from the study. However, their large sizes were anomalous: whereas most fish were $<100 \mathrm{~mm}$ TL and weighed $<6 \mathrm{~g}$, these fish were $>130 \mathrm{~mm}$ TL (up to $155 \mathrm{~mm}$ ) and weighed in excess of $12 \mathrm{~g}$ (up to $26 \mathrm{~g}$ ). Such large fish may have been using a different habitat than fish in the near-shore areas; however, in general juvenile shad appear to use near-shore areas during the daytime and move off-shore at night (Limburg pers. obs.).

In addition, 2 or 3 otolith trajectories from fish caught by beach seine in near-shore habitats in the lower Hudson estuary showed moderate to marked increases in $\mathrm{Sr}$ : Ca at various points. These variations may have arisen when saline water masses moved into the estuary as summertime freshwater flows declined; however, one might expect to see similar variations on all the otoliths from fish caught in that area, if they were present there during these proposed seawater intrusions. Alternatively, individual fish may have made excursions into waters of increased salinity, and then moved to lower salinity areas. Such movements might be either longitudinal (downriver to saltier waters, then retreat upriver) or horizontal (movement into deeper, more saline channels and then back into fresher shallows).
These results have important implications for our understanding of American shad life history. The Sr:Ca data provide evidence of departure (Table 5) from the natal freshwater environment much earlier than has been previously reported (Walburg \& Nichols 1969 , Leggett \& Whitney 1972, Leggett 1976, O'Leary \& Kynard 1986), and at a much younger age (ca 6 to $9 \mathrm{wk}$ old). Assuming the patterns of elevated Sr:Ca do reflect seawater entry, then these are the first data to confirm early (pre-autumn) out-migration of juvenile American shad from natal rivers, a phenomenon that has been hypothesized by Chittenden (1969) and Marcy (1976). Further, juvenile American shad may make brief forays back and forth between estuary and sea, or wander back into estuaries during the first year, phenomena which have not been reported at all.

To confirm adequately that the 3 'suspected vagrants' originated in another river system, temperature records from other spawning rivers would be needed, in addition to stock identification data, e.g. mitochondrial DNA or meristic information. If these are truly 'vagrants' from another population (Sinclair 1988), interesting questions could be posed. For instance, would these fish have eventually returned to their natal river to spawn, or alternatively would they have not shown natal river fidelity? Lack of fidelity to a natal river can have important consequences for the evolution of population structure.

The immediate fate of out-migrating young-of-year shad is largely unknown, although there is evidence that juveniles shoal just off the coast during the first winter (Milstein 1981). The relative success of early versus late out-migrants in terms of their contribution to spawning populations is also unknown. With the microprobe technique, it should be possible to examine the first year's growth in otoliths of returning adult shad, and to estimate fairly accurately the time of their departure from a natal freshwater environment. This information would shed light on successful migration strategies.

Acknowledgements. E. Brothers, S. Campana, N. Hairston, R. Howarth, C. Krueger, S. Levin, D. Secor, and 3 anonymous reviewers provided useful comments on earlier drafts. K. Hattala, A. Kahnle, and K. McKown, New York State Department of Environmental Conservation, provided specimens. J. Hunt, Materials Science Center, Cornell University, oversaw the microprobe work; M. Rutzke, Food and Vegetable Science Dept, Cornell University, conducted the ICP analysis. T. Dawson helped to obtain funding. This work was supported by the Electric Power Research Institute and by Cornell University.

\section{LITERATURE CITED}

Abood, K. A. (1974). Circulation in the Hudson estuary. Ann. N.Y. Acad. Sci. 250: 39-111

Albee, A. L., Ray, L. (1970). Correction factors for electron 
probe microanalysis of silicates, oxides, carbonates, phosphates, and sulfates. Analyt. Chem. 42: 1408-1414

Atkins, P. W. (1978). Physical chemistry. W. H. Freeman and Co., San Francisco

Backman, T. W., Ross, R. M. (1991). Comparison of three techniques for the capture and transport of impounded subyearling American shad. Prog. Fish Cult. 52: 246-252

Bernat, M., Church, T., Allegre, C. J. (1972). Barium and strontjum concentrations in Pacific and Mediterranean sea water profiles by direct isotope dilution mass spectrometry. Earth Planet Sci. Lett. 16: 75-80

Brass, G. W., Turekian, K. K. (1972). Strontium distributions in sea water profiles from the Geosecs I (Pacific) and Geosecs II (Atlantic) test stations. Earth Planet Sci. Lett. 16: $11 \bar{f}-121$

Broecker, W. S. (1974). Chemical oceanography. Harcourt Brace Jovanovich, Inc., New York

Brothers, E. B. (1987). Methodological approaches to the examination of otoliths in aging studies. In: Age and growth of fish. Summerfelt, R. C., Hall, G. E. (eds.) Iowa State University Press, Ames, p. 319-330

Brothers, E. B., Mathews, C. P., Lasker, R. (1976). Daily growth increments in otoliths from larval and adult fishes. Fish. Bull. U.S. 74: 1-8

Busby, M. W., Darmer, K. I. (1970). A look at the Hudson estuary. Water Resour. Bull. 6: 802-812

Campana, S. E., Neilson, J. D. (1985). Microstructure of fish otoliths. Can. J. Fish. Aquat. Sci. 42: 1014-1032

Casselman, J. M. (1982). Chemical analysis of the optically different zones in eel otoliths. In: Proc. 1980 North American eel conference. Ont. Fish. Tech. Rep. Ser. 4. Loftus, K. H. (ed.) Ont. Minist. Nat. Resour. p. 74-82

Chittenden, M. E. Jr (1969). Life history and ecology of the American shad, Alosa sapidissima, in the Delaware River. Ph.D. thesis, Rutgers University, New Brunswick

Coutant, C. C., Chen, C. H. (1993). Strontium microstructure in scales of freshwater and estuarine striped bass (Morone saxatilis) detected by laser ablation mass spectrometry. Can. J. Fish. Aquat. Sci. 50: 1318-1323

Culkin, F., Cox, R. A. (1966). Sodium, potassium, magnesium, calcium, and strontium in sea water. Deep Sea Res. 13: $789-804$

Dannevig, A. (1933). On the age and growth of the cod (Gadus callarias L.) from the Norwegian Skagerrack coast. Rep. Norw. Fish. mar. Invest. (FiskDir. Skr.) 4: 1-145

Dannevig, E. H. (1956). Chemical composition of the zones in cod otoliths. J. Cons. perm. int. Explor. Mer 21. 156-159

Degens, E. T., Deuser, W. G., Haedrich, R. L. (1969). Molecular structure and composition of fish otoliths. Mar. Biol. 2: $105-113$

Durum. W. H., Haffty, J. (1963). Implications of the minor element content of some major streams of the world. Geochim. Cosmochim. Acta 27. 1-11

Fabricand, B. P., Imimbo, E. S., Brey, M. E. (1968). Concentration changes of $\mathrm{Ca}, \mathrm{Cu}, \mathrm{Li}, \mathrm{Mg}, \mathrm{K}, \mathrm{Na}$, and $\mathrm{Sr}$ in the Hudson River, New York. J. sedim. Petrol. 38: 671-674

Firda, G. D., Lumin, R., Murray, P. M. (1991). Water resources yearbook for New York State, Water Year 1990. Volume I. U.S.G.S. Water-Data Report NY-90-1 United States Geological Survey, Albany, NY

Gauldie, R. W., Fournier, D. A., Dunlop, D. E., Coote, G. (1986). Atomic emission and proton microprobe studies of the ion content of otoliths of chinook salmon aimed at recovering the temperature life history of individuals. Comp. Biochem. Physiol. A 84:607-615

Goldstein, J. I., Newbury, D. E., Echlin, P., Joy, D. C., Fiori, C., Lifshin, E. (1981). Scanning electron microscopy and $x$-ray microanalysis. Plenum Press, New York

Gunn, J. S., Harrowfield, I. R., Proctor, C. H., Thresher, R. E. (1992). Electron probe microanalysis of fish otoliths evaluation of techniques for studying age and stock discrimination. J. exp. mar. Biol. Ecol. 158: 1-36

Hoff, G. R., Fuiman, L. A. (1993). Morphometry and composition of red drum otoliths: changes associated with temperature, somatic growth rate, and age. Comp. Biochem. Physiol. 106A: 209-219

Johnsen, J. H. (1966). The geology and mineral resources of the Hudson estuary. In: Hudson River ecology, 1st Symp. Hudson River Valley Commission, Tarrytown, NY, p. 8-40

Kalish, J. M. (1989). Otolith microchemistry: validation of the effects of physiology, age and environment on otolith composition. J. exp. mar. Biol. Ecol. 132: 151-158

Kalish, J. M. (1990). Use of otolith microchemistry to distinguish the progeny of sympatric anadromous and nonanadromous salmonids. Fish. Bull. U.S. 88; 657-666

Kinsman, D. F. F., Holland, H. D. (1969). The coprecipitation of cations of $\mathrm{CaCO}_{3}$. IV The coprecipitation of $\mathrm{Sr}^{2+}$ with aragonite between $16^{\circ}$ and $96^{\circ} \mathrm{C}$. Geochim. Cosmochim. Acta 33: 1-17

Kulp, J. L., Turekian, K., Boyd, D. W. (1952). Strontium content of limestones and fossils. Bull. geol. Soc. Am. 63: $701-716$

Leggett, W. C. (1976). The American shad (Alosa sapidissima), with special reference to its migration and population dynamics in the Connecticut River. In: The Connecticut River ecological study. Merriman, D., Thorpe, L. M. (eds.) Am. Fish. Soc., Monograph No. 1. p. 169-225

Leggett, W. C., Whitney, R. R. (1972). Water temperature and the migrations of American shad. Fish. Bull. U.S. 70: $659-670$

Lemm, C. A., Rottiers, D. V., Dropkin, D. S., Dennison, B. A. (1988). Growth, composition, and fin quality of Atlantic salmon fed different diets at seasonal temperatures in a laboratory and hatchery. Biol. Rep. U.S. Fish Wildl. Ser., 88(8): $1-12$

Limburg, K. E. (1994). Ecological constraints on growth and migration of juvenile American shad (Alosa sapidissima Wilson) in the Hudson River estuary, New York. Ph.D. dissertation, Cornell University, Ithaca

Limburg, K. E., Moran, M. A., McDowell, W. H. (1986). The Hudson River ecosystem. Springer-Verlag, New York

LMS (1992). 1990 year class report for the Hudson River Estuary Monitoring Program. Prepared for Consolidated Edison of New York, Inc. LMSE-92/0031\&115/158. Lawler, Matusky \& Skelly Engineers, Pearl River, NY

Marcy, B. C. Jr (1976). Early life history studies of American shad in the lower Connecticut River and the effects of the Connecticut Yankee plant. In: The Connecticut River ecological study. Merriman, D., Thorpe, L. M. (eds.) Am. Fish. Soc. Monograph No. 1. p. 141-168

McCrone, A. W. (1966). The Hudson River sediments. In Hudson River ecology, 1st Symp. Hudson River Valley Commission, Tarrytown, NY, p. 41-59

Milstein, C. B. (1981). Abundance and distribution of juvenile Alosa species off southern New Jersey. Trans. Am. Fish. Soc. 110: 306-309

Moyle, P. B., Cech, J. J. Jr (1988). Fishes: an introduction to ichthyology, 2nd edn. Prentice Hall, Englewood Cliffs, NJ

Mugiya, Y., Hakomori, T., Hatsutori, K. (1991). Trace metal incorporation into otoliths and scales in the goldfish. Carassius auratus. Comp. Biochem. Physiol 99C: 327-331

Odum, H. T. (1951). Notes on the strontium content of sea water, celestite Radiolaria, and strontianite snail shells. Science 114: 211-213 
Odum, H. T. (1957a). Strontium in natural waters. Publs. Inst. mar. Sci. Univ. Tex. 4: 22-37

Odum, H. T. (1957b). Biogeochemical deposition of strontium. Pubis. Inst. mar. Sci. Univ. Tex. 4: 38-114

O'Leary, J. A., Kynard, B. (1986). Behavior, length, and sex ratio of seaward-migrating juvenile American shad and blueback herring in the Connecticut River. Trans. Am. Fish. Soc. 115: 529-536

Pannella, G. (1971). Fish otoliths: daily growth layers and periodic patterns. Science 173: 1124-1127

Radtke, R. L. (1984). Cod fish otoliths: information storage structures. The propagation of cod Gadus morhua L. Flødevigen rapportser. 1: 273-298

Radtke, R. L. (1989). Strontium-calcium concentration ratios in fish otoliths as environmental indicators. Comp. Biochem. Physiol. 92A: 189-193

Radtke, R. L., Kinzie, R. A. III, Folsom, S. D. (1988). Age at recruitment of Hawaiian freshwater gobies. Environ. Biol. Fish. 23: 205-191

Reibisch, J. (1900). Über Eizahl bei Pleuronectes platessa und die Altersbestimmung dieser Form aus den Otolithen. Wiss. Meeresunters. (Abt. Kiel) 4: 233

Riley, J. P., Chester, R. (1971). Introduction to marine chemistry. Academic Press, London

Riley, J. P., Tongudai, M. (1967). The major cation/chlorinity ratios in sea water. Chem. Geol. 2: 263-269

Savoy, T. F., Crecco, V. A. (1987). Daily increments on the otoliths of larval American shad and their use in population dynamics studies. In: Summerfelt, R. C., Hall, G. E. (eds.) Age and growth of fish. Iowa State University Press, Ames, p. 413-432

Schmidt, R. E., Klauda, R. J., Bartels, J. M. (1988). Distributions and movements of the early life stages of three species of Alosa in the Hudson River, with comments on mechanisms to reduce interspecific competition. In:

This article was submitted to the editor
Smith, C. L. (ed.) Fisheries Research in the Hudson River. State University of New York Press, Albany, p. $193-215$

Secor, D. H. (1992). Application of otolith microchemistry analysis to investigate anadromy in Chesapeake Bay striped bass Morone saxatilis. Fish. Bull. U.S. 90: 798-806

Secor, D. H., Dean, J. M., Campana, S. E. (eds.) (1994). Recent advances in fish otolith research. University of South Carolina Press, Columbia, SC

Secor, D. H., Henderson-Arzapalo, A., Piccoli, P. M. (1995). Can otolith microchemistry chart patterns of migration and habitat utilization in anadromous fishes? J. exp. mar. Biol. Ecol. (in press)

Simpson, H. J., Bopp, R., Thurber, D. (1974). Salt movement patterns in the lower Hudson. Paper 9. In: Hudson River ecology, 3rd Symp. Hudson River Environmental Society, Bronx, NY

Sinclair, M. (1988). Marine populations: an essay on population regulation and speciation. Washington Sea Grant Program, University of Washington Press, Seattle

Skougstad, M. W., Horr, C. A. (1963). Occurrence and distribution of strontium in natural water. Geological Survey Water-Supply Paper 1496-D. U.S. Geological Survey, p. 55-97

Summerfelt, R. C., Hall, G. E. (1987). Age and growth of fish. lowa State University Press, Ames

Talbot, G. B. (1954). Factors associated with fluctuations in abundance of Hudson River shad. Biol. Rep. U.S. Fish Wildl. Serv. 101(56): 373-413

Turekian, K. K., Kulp, J. L. (1956). The geochemistry of strontium. Geochim. Cosmochim. Acta 10: 245-296

Walburg, C. H., Nichols, P. R. (1969). Biology and management of American shad and status of the fisheries, Atlantic coast of the United States, 1960. U.S. Fish Wildl. Serv. biol. Rep., Spec. Sci. Rep. Fish. 550

Manuscript first received: April 27, 1994

Revised version accepted: December 18, 1994 